\title{
FILOLOGICKÉ VĚDY
}

UDC 81 '37

DOI: $10.24045 / \mathrm{pp} .2017 .1 .12$

\section{NATIONAL PECULIARITIES IN PERCEPTION OF THE SEASONS IN THE RUSSIAN AND ENGLISH LANGUAGES (on psycholinguistic experiment data)}

E. Grudeva
Candidate of Philological Sciences

Stavropol' State Agrarian University Stavropol, Russian Federation

\begin{abstract}
Absract. The article presents the results of a psycholinguistic experiment, aimed to identify and describe the conceptual layer of the concepts summer and autumn in the minds of modern native Russian and English languages speakers and thus to show the difference in perception of the concepts of the seasons. As the concept is a multidimensional unit, which includes not only meaning and definition, but also connotative, figurative, evaluation, associative characteristics so all of them must be taken into account when describing the concept. These characteristics may be considered as signs of difference in mentality of different nations.

Keywords: concept; conceptual layer; ethno-specificity; cross-language mapping; national mentality; national concept sphere; semantics; semema; lexeme; cognitive signs; psycholinguistic experiment.
\end{abstract}

As any comparative study, the study of the concepts is aimed at identifying the distinctive features of the object: the establishment of its ethno-cultural features, which is understood. As the ethno-specificity may be a sign that formed the basis of the nomination, - that is an internal form of the name. Ethno-specificity might be viewed in stereotyping models of perception and behavioral reactions, reflected in the semantics of the concept. Ethno-specificity of the concept in the context of cross-language mapping gives grounds to consider it as a unit of national mentality, different from the mentality as a general totality of the features of the national character [1].

As it is known, representatives of multilingual societies perceive and appreciate the world around in a different way. The basis of the national character, temperament and national mentality are formed by the external conditions of the language community existence and its cultural traditions.

Mapping semantic spaces of different languages allows to see the human sameness in reflection of surrounding world as well as gives the opportunity to see the specific, national, and then group and individual set of concepts and their structuring. National specific of semantics reflects national peculiarities of the language consciousness of two nations and can be used to simulate the corresponding concepts as units of the national concept sphere. Nationally specific semes which were revealed by comparing lexical units of two languages are interpreted as a reflection of nationally specific characteristics of the respective national concepts and allow to model the concept and reveal its national-specific characteristics [1].

The subject of our research are the concepts summer and autumn as elements of the 
national concept sphere that carry out the function of collective language consciousness units. While working at our research, we have defined our goal not only to model the concepts, but what seems to be the most important - to compare the concepts in the Russian and English languages and to identify similar and different components in the structure of the mentioned concepts.

To identify the conceptual layer of the concepts, we turned to the explanatory dictionaries of the Russian and English languages of the XX century. For the analysis of the words "summer" and "autumn" we used the explanatory dictionaries of the Russian language by D. Ushakov, S. Ozhegov, "Russian Semantic Dictionary" by N. Shvedova, and "The Explanatory Dictionary of the Live Great Russian Language" by V. Dal to match modern lexemes and earlier stage of their existence. To analyze the English words "summer" and "autumn", we have turned to the explanatory dictionary of the English language "Chambers' 20th Century Dictionary" (1983), "Cambridge International Dictionary of English", "New Webster's Dictionary of the English Language" (1988) and "Webster's New International Dictionary" (Merriam Webster).

On analyzing the definitions of the words "summer" and "autumn" presented in the dictionaries we concluded that the two main sememas given in English and in Russian explanatory dictionaries - summer is the warmest time of the year and summer $=$ year - are match, so we can highlight them as conceptual characteristics of this concept; semema summer - the period of accumulation of forces, maturing, and the period of youth, beauty, flourishing of life and success, not represented in the Russian explanatory dictionaries. It is also noteworthy that the astronomical features of the lexeme "summer" is represented in all monolingual dictionaries of the English language, and among the explanatory dictionaries of the Russian language astronomical characteristic of seasons as a whole and semema "summer" in particular presented only in the dictionary by V. Dal [2].

As for the word "autumn", it is obvious that the main semema presented in English and in Russian explanatory dictionaries - autumn - the time period between summer and winter and autumn is the period of maturity and gradual fading - are coincide.

All the dictionary definitions we have analyzed reflect so-called "lexicographic set" of the words "summer" and "autumn" and represent the fixation of the main components of the conceptual layer of the national concept that reflects such basic cognitive signs as period of time, sequence and temperature characteristic of these times of the year. Taking into account I. A. Sternin's opinion that lexicographic meaning of the word is always much narrower than it psychologically real meaning [3] to expand the conceptual layer of the studied concepts and find out whether their "lexicographic meaning" from the images that arise in the minds of native speakers, we turned to the results of psycholinguistic experiment, namely, interpretative analysis, and suggested our respondents to continue the phrase: "In Your opinion, summer/autumn is...". On the basis of the responses received it was found that the conceptual layer of the concept summer in the minds of modern native Russian language speakers presents the components, indicating:

period of time : June, July, August; a very short time of the year;

temperature characteristics: heat, stuffiness, lot of sun, warmth;

emotional characteristic of the year: the best time of the year; favorite time of the year; happiness; little life; a lot of free time; a good mood; carelessness; peace; freedom.

human activities: holidays, vacation, session, girls in summer clothes, the sea, renovated, when hot water cut off a trip to rela-

Paradigmata poznóní. I . 2017 
tives, traveling, new acquaintances, football, tennis, fishing, free time.

As for the Russian concept autumn following cognitive signs can be distinguished:

period of time: the time of year; season; September, October, November;

atmospheric phenomena: rain, wind, dirt, humidity, fog;

emotional characteristic of the season: the Golden plates; trees in gold; the most beautiful time of the year; romantic time of the year; very boring; withering of nature; depression, sadness, fatigue;

human activity: beginning of academic year; September; preparation for the winter; warm clothing; the beginning of a new stage in life, the anticipation of change; meeting with old friends; work, the return from leave.

English-speaking respondents were also asked to continue the phrase that sounded as follows: "From your point of view summer/autumn means...". From the responses received, we have identified the following cognitive signs of the English concept summer:

period of time: summer months; June, July, August;

temperature characteristics: sunny days, warmth, hot, tank top weather;

emotional characteristics: great time, great days, happiness, love, best time of the year, freedom, laziness, dog days, relaxation, liveliness, joy, dreamy;

human activities: volleyball, holiday, football championship, climbing trees, diving, summer festivals, rafting, baseball, joyrides, night walks in the warm air, barbeque, camping, jump in the pool, picnics, fishing;

Conceptual layer of the concept autumn of the English-speaking respondents are represented by the following components:

period of time: autumn months; September, October, November; equinox;

atmospheric phenomena: rain, wind, icy windshields in the morning, clear, crisp air, dazzeling sunsets, evening coolness, morning dew, mists;

emotional characteristic of the season: dull gray days; yellow leaves; the most beautiful season of the year, depression, favorite season;

human activities: holidays, stay at home, Halloween, starting kindergarten, Thanksgiving, lazy days in front of a fire, home cooking, fair;

Comparing dictionary definitions and definitions proposed by native speakers, we can conclude that the cognitive signs that form the conceptual layer of the concepts summer and autumn in dictionary definitions are sufficiently reduced, because they include only components of natural character. The method of interpretation analysis has allowed us to fix the psychological meaning of the words. This psychological meaning, according to I.A. Sternin, is an extension of the conceptual layer of the concept through individual associations, deliberate linguistic consciousness [3, c. 257-282]. In this case, the extension of the conceptual layer occurs due to the verbalization of such cognitive signs of the concepts as "emotional characteristic time of the year" and "human activity".

\section{Bibliography}

1. Воркачев С. Г. Лингвокультурология, языковая личность, концепт: становление антропоцентрической парадигмы в языкознании // Филологические Науки. - 2001, - № 1. - С. 64-72.

2. Даль В. Толковый словарь живого великорусского языка - М., Русский язык, 1981.

3. Стернин И. А. Типы значений и концепт // Концептуальное пространство языка: сб. науч. тр. Посвящается юбилею профессора Н. Н. Болдырева. - Тамбов : Изд-во ТГУ им. Г. Р. Державина, 2005. - С. 257-282.

4. Ожегов С. И., Шведова Н. Ю. Толковый словарь русского языка. - М. : АЗЬ, 1995. - 928 с.

5. Русский семантический словарь / под общей редакцией Н. Ю. Шведовой. - М. : Азбуковник, 2003. -653 c.

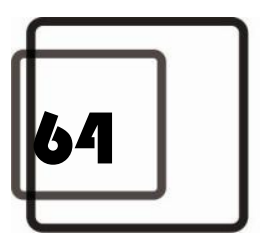


6. Cambridge International Dictionary of English http://www.cambridge.org

7. Chambers $20^{\text {th }}$ Century Dictionary / W. Chambers. Limited London and Edinburg, 1996.

8. New Webster's Dictionary of The English Language. Delhi, 1988.

\section{Bibliography}

1. Vorkachev S. G. Lingvokul'turologija, jazykovaja lichnost', koncept: stanovlenie antropocentricheskoj paradigmy v jazykoznanii // Filologicheskie Nauki. - 2001, - № 1. - S. 64-72.

2. Dal' V. Tolkovyj slovar' zhivogo velikorusskogo jazyka-M., Russkij jazyk, 1981.

3. Sternin I. A. Tipy znachenij i koncept // Konceptual'noe prostranstvo jazyka: sb. nauch. tr.
Posvjashhaetsja jubileju professora N. N. Boldyreva. - Tambov : Izd-vo TGU im. G. R. Derzhavina, 2005. - S. 257-282.

4. Ozhegov S. I., Shvedova N. Ju. Tolkovyj slovar' russkogo jazyka. - M. : AZ, 1995. - $928 \mathrm{~s}$.

5. Russkij semanticheskij slovar' / pod obshhej redakciej N. Ju. Shvedovoj. - M. : Azbukovnik, 2003. $-653 \mathrm{~s}$.

6. Cambridge International Dictionary of English http://www.cambridge.org

7. Chambers 20th Century Dictionary / W. Chambers. Limited London and Edinburg, 1996.

8. New Webster's Dictionary of The English Language. Delhi, 1988.

(C) Grudeva E., 2017. 